\title{
Relationship Between the Level of Knowledge and Attitude of Aged Women About Early Detection of Cancer Leaf Cancer With Behavior of Examination of Acetic Acid Inspection
}

\author{
$1^{\text {st }}$ Imas Nurjanah \\ Midwifery Study Program \\ Akademi Kebidanan Prima Husada Bogor \\ Bogor, Indonesia \\ Indiranurjanah83@gmail.com
}

\author{
$2^{\text {nd }}$ Nina Yusnia \\ Midwifery Study Program \\ Akademi Kebidanan Prima Husada Bogor \\ Bogor, Indonesia \\ bidan01nina@gmail.com
}

\begin{abstract}
According to an evaluation in early 2016 the coverage of IVA exams in Bogor City was still very low at around $10.4 \%$. This is far from the target of the Bogor City Health Office, which in 85 years is $85 \%$ or an annual target of $20 \%$ of the population at risk. The purpose of this study was to determine the relationship of the level of knowledge and attitudes of women of childbearing age about early detection of cervical cancer with an examination of Visual Acetic Acid Inspection behavior in the working area of the Tanah Sareal Health Center. The method used is an analytical method with a cross-sectional approach. The population is all women of childbearing age at the Tanah Sareal Health Center of $\mathbf{4 3 0}$ people using a total sampling of 430 according to inclusion criteria. The results of the research based on knowledge showed as many as 259 respondents $(60.2 \%)$ with less knowledge, attitudes showed many as 333 respondents $(\mathbf{7 7 . 4 \%})$ with negative attitudes, behavior showed as many as 313 respondents $(\mathbf{7 2 . 8 \%})$ who had never conducted an examination IVA, and there is a relationship between knowledge with IVA examination behavior $(p=0.036)$ with COR 1.581 , there is a relationship between attitude with IVA examination behavior $(p=0,000)$ with COR 2,627. The conclusion of this study shows that there is a relationship between knowledge and attitude with IVA examination behavior and is influenced by attitude, information exposure, husband / family support, knowledge, and age. women of childbearing age.
\end{abstract}

Keywords-knowledge, attitude, examination, cervical cancer

\section{INTRODUCTION}

In 1980 WHO recommended an alternative approach for developing countries against cervical cancer, one of which was by Visual Acetate (IVA) Inspection. Examination IVA is an alternative Pap smear screening examination because it is cheap, practical, very easy to implement and simple equipment and can be done by health workers besides gynecology doctors. IVA examination can be done by all health workers, especially midwives $^{[1]}$

In Indonesia, the prevalence of cancer is also quite high. Based on the 2013 Riset Kesehatan Data (Riskesdas), the prevalence of cancer in Indonesia is 1.4 of 1000 population, or around 330,000 people. The highest cancers in Indonesia in women are breast cancer and cervical cancer. Based on Globocan's estimation, International Agency for Research on Cancer (IARC) in 2012, 17 cervical cancers of 100,000 women, Based on 2012 Sistem Informasi Rumah Sakit (SIRS), inpatient cases of cervical cancer in 5,349 cases $(12.8 \%)^{[2]}$.

The best prospect in the prevention of cancer is to make people aware through health education. If women, especially mothers, get enough knowledge about the dangers of cervical cancer and the benefits of IVA examination, they will realize the importance of early detection and prevention. Until now, most Indonesian people, especially women, are still relatively unfamiliar with the importance of Visual Inspection with Acetic acid (IVA) or pap smears to detect the possibility of having cervical cancer early ${ }^{[3]}$.

Study literature on January $10^{\text {th }} 2016$ at the Puskesmas Tanah Sareal based on a final coverage report in 2015 of a population of 4,154, including $241(5.8 \%)$ women had IVA examinations and 7 people with IVA (+) results, and suspected cervical cancer two persons. Compared to other puskesmas, Puskesmas Kedung Badak and Bondongan IVA coverage $10.2 \%$, Puskesmas Cipaku $12.6 \%$, Puskesmas Tegal gundil 15\% , Puskesmas Mekarwangi , Puskesmas Pulo Armin , Bogor Tengah 25 $\%$ and Puskesmas Sindang Barang 22\%, then Puskesmas Tanah sareal is among the lowest in coverage.

\section{RESEARCH METHOD}

This research uses analytic method with crosssectional approach. This research will be conducted in January to May 2016 in the Work Area of Tanah Sareal Health Center, Bogor City. The population in this study were all women of childbearing age who married and visited the working area of the Tanah Sareal Community Health Center in Bogor City in 2015. The sample size in this study was calculated using the formula ${ }^{[4]}$. the number of samples needed 430 WUS to meet the research objectives. The sampling technique in this study was to take all married WUS and visit the work area of the Tanah Sareal Community Health Center. Data collected in this study are primary data. 


\section{RESULT AND DISCUSSION}

TABLE 1 DISTRIBUTION OF WUS KNOWLEDGE, ATTITUDE AND BEHAVIOR FREQUENCY IN VIA EXAMINATION

\begin{tabular}{|l|l|c|}
\hline Variable & Category & $\%$ \\
\hline Knowledge & Good & 39,8 \\
\cline { 2 - 3 } & Not Good & 60,2 \\
\hline \multirow{2}{*}{ Attitude } & Positive & 22,6 \\
\cline { 2 - 3 } & Negative & 77,4 \\
\hline \multirow{2}{*}{ WUS Behavior } & Do & 27,2 \\
\cline { 2 - 3 } & Do Not & 72,8 \\
\hline
\end{tabular}

Based on table 1 knowledge shows as many as 259 respondents $(60.2 \%)$ with less knowledge. Based on attitude showed 333 respondents $(77.4 \%)$ with a negative attitude. The sample size in this study was calculated using the formula. So the number of samples needed in this study was 429.3 WUS rounded to 430 WUS to meet the research objectives. Based on behavior shows as many as 313 respondents $(72.8 \%)$ who have never conducted an IVA examination.

TABLE 2 THE RELATIONSHIP BETWEEN KNOWLEDGE AND BEHAVIOR OF IVA EXAMINATION IN THE WORK AREA OF TANAH SAREAL HEALTH CENTER, BOGOR CITY IN 2016

\begin{tabular}{|c|c|c|c|c|c|}
\hline \multirow[t]{3}{*}{ Knowledge } & \multicolumn{2}{|c|}{$\begin{array}{c}\text { IVA } \\
\text { Examination } \\
\text { Behavior }\end{array}$} & \multirow[t]{2}{*}{ Total } & \multirow[t]{3}{*}{$p$ value } & \multirow[t]{2}{*}{$\begin{array}{c}\text { COR } \\
(95 \% \\
\text { CI })\end{array}$} \\
\hline & $\begin{array}{l}\text { Do } \\
\text { Not }\end{array}$ & Do & & & \\
\hline & $\%$ & $\%$ & $\%$ & & \\
\hline Not Good & $\begin{array}{l}76,4 \\
67,3\end{array}$ & $\begin{array}{l}23,6 \\
32,7\end{array}$ & $\begin{array}{l}100 \\
100\end{array}$ & 0,036 & $\begin{array}{c}1,581 \\
(1,029- \\
2,248)\end{array}$ \\
\hline Good & & & & & \\
\hline Sum & 72,8 & 27,2 & 100 & & \\
\hline
\end{tabular}

The results of the analysis of the relationship between knowledge and IVA examination behavior showed that the proportion of WUS who did IVA examinations was 56 $(32.75 \%)$ well-informed and as many as $61(23.6 \%)$ were less knowledgeable. There is a meaningful relationship between knowledge and the behavior of WUS in conducting IVA checks.

TABLE 3 RELATIONSHIP BETWEEN ATTITUDE AND BEHAVIOR OF IVA EXAMINATION IN THE WORK AREA OF TANAH SAREAL HEALTH CENTER, BOGOR CITY IN 2016

\begin{tabular}{|c|c|c|c|l|c|}
\hline \multirow{2}{*}{ Attitude } & \multicolumn{2}{|c|}{$\begin{array}{c}\text { IVA Examination } \\
\text { Behavior }\end{array}$} & Total & $\begin{array}{l}p \\
\text { value }\end{array}$ & $\begin{array}{c}\text { COR } \\
(95 \% \mathrm{CI})\end{array}$ \\
\cline { 2 - 4 } & Do Not & Do & & & \\
\cline { 2 - 4 } & $\%$ & $\%$ & $\%$ & & \\
\hline Negative & 77,5 & 22,5 & 100 & 0,000 & 2,627 \\
Positive & 56,7 & 43,3 & 100 & & $(1,631-$ \\
& & & & & $4,232)$ \\
\hline Sum & 72,8 & 27,2 & 100 & \multicolumn{3}{|c|}{} \\
\hline
\end{tabular}

The results of the analysis of the relationship between attitude and IVA examination behavior obtained the proportion of WUS who did IVA examination as many as $75(22.5 \%)$ had negative attitudes and as many as 42 $(43.3 \%)$ had positive attitudes. there is a meaningful relationship between attitude and WUS Behavior.
TABLE 4 MULTIVARIATE MODELING RESULTS OF KNOWLEDGE, ATTITUDE, AGE, HUSBAND / FAMILY SUPPORT, INFORMATION EXPOSURE TO CONDUCTING IVA

\begin{tabular}{|l|c|c|c|c|c|}
\hline \multicolumn{1}{|c|}{ Variable } & $\mathrm{B}$ & $\mathrm{SE}$ & Wald & P value & AOR (95\%) \\
\hline Attitude & 0,983 & 0,257 & $\begin{array}{c}14,56 \\
9\end{array}$ & 0,000 & $\begin{array}{c}2,671 \\
(1,613-4,425)\end{array}$ \\
\hline $\begin{array}{l}\text { Information } \\
\text { Exposure }\end{array}$ & 0,681 & 0,233 & 8,517 & 0,004 & $\begin{array}{c}1,975 \\
(1,251-3,120)\end{array}$ \\
\hline $\begin{array}{l}\text { Family/Hus } \\
\text { band } \\
\text { Support }\end{array}$ & 0,676 & 0,233 & 8,413 & 0,004 & $\begin{array}{c}1,965 \\
(1,245-3,103)\end{array}$ \\
\hline Knowledge & 0,470 & 0,234 & 4,043 & 0,044 & $\begin{array}{c}1,599 \\
(1,012-2,528)\end{array}$ \\
\hline Age & - & 0,259 & 5,870 & 0,015 & $\begin{array}{c}0,534 \\
(0,321-0,887)\end{array}$ \\
\hline
\end{tabular}

The results of the analysis, it is known that the Attitude variable, it is known that WUS with a positive attitude have the opportunity to do an IVA examination of 2.671 times after being controlled by variables with age, good knowledge, husband / family support and good information exposure to the WUS group who did not conduct IVA examination. In the information exposure variable, it is known that WUS with good information exposure have the opportunity to conduct IVA examination as much as 1,975 times after being controlled by variables with age, good knowledge, husband / family support and positive attitudes on groups of women who do not conduct IVA examination.

\section{A. Knowledge}

Health education using a cervical cancer prevention guidebook is very effective in increasing women's knowledge and participation in VIA examination.

This is also supported by the results of research by Wulandari (2019) The results of the analysis show the value of $p=0.003$ so that $p<0.05$ means that Ho is rejected and $\mathrm{Ha}$ is accepted, so there is a significant relationship between women's knowledge of reproduction

about the IVA Test with the behavior of the IVA Test. While the results of the contingency coefficient are 0.337 means low closeness.

\section{B. Attitude}

The factors that influence the attitudes of women of childbearing age such as the environment, socio-culture and economics so that they can determine whether they have an attitude of disapproval about the importance of early detection of cervical cancer so their attitude is not $\operatorname{good}^{[5]}$.

This study is in line with research from Kurniawati, $\mathrm{W}, 2019$, with the results of the chi square continuity correction test obtained $\mathrm{p}$ value of 0,000 Because $\mathrm{p}$-value $=0,000<\alpha(0.05)$, it can be concluded that there is a significant relationship between attitudes with the management of the behavior of women of childbearing age in early detection of cervical cancer.

\section{CONCLUSIONS AND SUGGESTIONS}

There is a significant relationship between knowledge with WUS Behavior in conducting VIA Inspection in the work area of the Puskesmas Tanah Sareal, with COR 1,581 (95\% CI: $1,029-2,248)$ meaning WUS who conduct 
IVA examinations have a 1.581 times greater chance of knowledge when compared to with WUS who are wellinformed in the group that doesn't have an IVA check.

There is a significant relationship between attitude and IVA Checking Behavior in the working area of Puskesmas Tanas Sareal with COR 2,627 (95\% CI: 1,631-4,232), meaning that WUS who conduct IVA examinations have a positive attitude of 2,627 times greater than WUS who have a positive attitude to the group that doesn't an IVA examination.

Suggestions in this research are conducting health education activities about early detection of cervical cancer by IVA method by health workers both formally and informally, expanding health promotion goals, disseminating information about IVA examination methods through print media and mass media, increasing the empowerment of cadres, women of childbearing age, health workers add material content in addition to theories about cervical cancer but also provide an overview of IVA examination.

\section{ACKNOWLEDGMENT}

This research supported by Akademi Kebidanan Prima Husada Bogor.

\section{REFERENCES}

[1] Wulandari, FI, Angelina, M, Nuwwaridya, Destil, H, Sudiro TM. 2019. Relationship of Reproductive Women's Knowlegde On Visual Inspection of Acetic Acid (Iva Test) With Iva Behaviour Test. 1st International Respati Health Conference (IRHC). file:///G:/ICoSHEET\%202019/JURNAL\%20REFERENSI/108216-1-SM.pdf. Jurnal. Diakses tanggal 04 Januari 2020.

[2] Kementerian Kesehatan RI.(2015). Program Nasional Gerakan Pencegahan dan deteksi Dini Kanker Leher Rahim dan Payudara, Bakti Husada. http://www.scribd.com/doc/288299871/BukuPanduan-Pelaksanaan-IVA-SADANIS-2015\#scribd. Diakses Tanggal 02 Februari 2016

[3] Nisak, AZ, Wigati, A, Cholifah, N, Fanani, Z. 2019. The Effectiveness of The Use of Cervical Cancer Prevention Guideline Book on Women Participation in Visual Inspection with Acetic acid (VIA). Advances in Health Sciences Research, volume 15. file://G:/ICoSHEET\%202019/JURNAL\%20REFERENSI/019.pd f. Jurnal. Diakses tanggal 04 Januari 2020.

[4] Lemeshow, Stanley, dkk. (2015). Besar Sampel Dalam Penelitian Kesehatan. Ed. Bahasa Indonesia. Yogyakarta. Gadjah Mada University Press.

[5] Kurniawati,W, Shih, CJ, Diep, DN, Nhan, PN, Yafeli, F, Pangestu, DA. 2018. The Relationship Between Attitude on Behavior Management in Early Detection of Cervical Cancer Using Visual Inspection Acetic Acid (IVA). ISSN: 2455-3689 Volume 2 Issue 12. file:///G:/ICoSHEET\%202019/JURNAL\%20REFERENSI/IJRTE M_A02120104.pdf. Jurnal. Diakses 04 Januari 2020.

[6] Anggraeni, N. 2015. Hubungan Tingkat Pengetahuan Tentang Kanker Serviks Dengan Perilaku Wus Melakukan Pemeriksaan Iva Di Puskesmas Banguntapan I Bantul. file:///G:/ICoSHEET\%202019/JURNAL\%20REFERENSI/Naskah \%20Publikasi\%20Nobelia\%204297.pdf. Jurnal. Diakses 04 Januari 2020.

[7] Chosamata, MS, Hong, SA, Tiraphat, S. 2015. Determinants of cervical cancer screening utilization among women aged 30-45 years in Blantyre district, Malawi. Journal of Public Health and Development $\quad$ Vol. $\quad 13 \quad$ No. 3. file:///G:/ICoSHEET\%202019/JURNAL\%20REFERENSI/37669Article\%20Text-122029-1-10-20160322.pdf. Jurnal. Diakses 04 Januari 2020.

[8] Damailia, HT, Oktavia, TR. 2014. Faktor-Faktor Determinan Deteksi Dini Kanker Serviks melalui Metode Pap Smear pada Pasangan Usia Subur (PUS). GASTER Vol. XII No. 2 Agustus
2015.

file://G:/ICoSHEET\%202019/JURNAL\%20REFERENSI/95-

186-1-SM.pdf. Jurnal. Diakses tanggal 04 Januari 2020.

[9] Dinas Kesehatan Kota Bogor. 2015. Laporan cakupan pelayanan IVA.

[10] Ifeanyichukwu, OA. 2015. Cervical Cancer Knowledge and Screening Practices among Women of Reproductive Age in Benin City, Edo State. Journal Of Community Medicine And Primary Health Care VOL. 27, NO 2. file:///G:/ICoSHEET\%202019/JURNAL\%20REFERENSI/139383 -371896-1-SM.pdf. Jurnal. Diakses 04 Januari 2020.

[11] Irianto, Koes. (2015). Kesehatan Reproduksi (Reproductive Health). Bandung. Alfabeta, cv.

[12] Kementerian Kesehatan RI. (2015). Hilangkan mitos tentang kanker.

http://www.depkes.go.id/article/print/201407070001/hilangkanmitos-tentang-kanker.html. Diakses tanggal 15 desember 2015.

[13] Lestari, MA. 2016. Hubungan Pengetahuan Dan Sikap Wus Dengan Perilaku Melakukan Pemeriksaan Iva Di Kelurahan Kotabaru Wilayah Kerja Puskesmasgondokusumanii Yogyakarta. file:///G:/ICoSHEET\%202019/JURNAL\%20REFERENSI/NASK AH\%20PUBLIKASI\%20TERBARU\%20FIX.pdf. Jurnal. Diakses 04 Januari 2020

[14] Mantula, Fennie. 2015. Uptake of Visual Inspection With Acetic Acid And Cervicography Screening Among Women Attending Gwanda Provincial Hospital In Zimbabwe. file:///G:/ICoSHEET\%202019/JURNAL\%20REFERENSI/Final\% 20corrected $\% 20$ Research $\% 20$ Report $\% 20$ for $\% 20$ submissionfennie.pdf. Jurnal. Diakses 04 Januari 2020.

[15] Puskesmas Tanah Sareal. (2015). Data cakupan pemeriksaan IVA Tahun 2015

[16] Puskesmas Tanah Sareal. (2015). Profil Puskesmas Tanah Sareal Tahun 2015

[17] Saputri, MA. 2016. Hubungan Tingkat Pengetahuan Tentang Test Inspeksi Visual Asam Asetat (Iva) Dengan Keikutsertaan Wanita Dalam Melakukan Pemeriksaannya Di Desagodegan Mojolaban Sukoharjo.

file://G:/ICoSHEET\%202019/JURNAL\%20REFERENSI/NASK AH\%20PUBLIKASI.pdf. Jurnal. Diakses 04 Januari 2020.

[18] Zuliani, Elvi. 2014. Pelaksanaan IVA Dalam Screening Ca Serviks. http://www.pelaksanaan iva14.com.html 